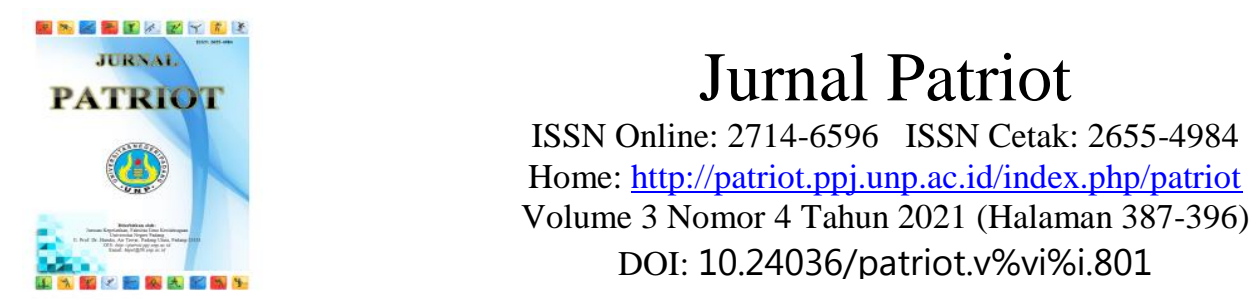

\title{
Meningkatkan Konsentrasi Atlet Sepak Bola melalui Metode Latihan Life Kinetik
}

\author{
Agung Mulyadi $^{1 *}$, Komarudin $^{2}$, Hadi Sartono $^{3}$, Geraldi Novian ${ }^{4}$ \\ ${ }^{1,2,3}$ Program Studi Pendidikan Kepelatihan Olahraga, Fakultas Pendidikan Olahraga dan \\ Kesehatan, Universitas Pendidikan Indonesia, Indonesia \\ ${ }^{4}$ Program Studi Pendidikan Olahraga, Sekolah Pascasarjana, Universitas Pendidikan Indonesia, \\ Indonesia \\ Email Korespondensi: agungmulyadi1414@gmail.com
}

Dikirim: 24 Juli 2021 Direvisi: 1 November 2021 Diterbitkan: 25 November 2021

\begin{abstract}
ABSTRAK
Konsentrasi merupakan salah satu aspek psikologis yang sangat diperlukan atlet, namun latihan psikologis masih jarang dilakukan dalam cabang olahraga sepak bola, sehingga sering kali atlet mengalami kesulitan terkait hal tersebut. Oleh sebab itu, dibutuhkan metode latihan psikologis yang tepat untuk membantu mengatasi masalah tersebut, salah satu metode latihan psikologis yang sedang ramai saat ini yaitu metode latihan life kinetik. Penelitian ini bertujuan untuk mengkaji pengaruh yang signifikan metode latihan life kinetik terhadap peningkatan konsentrasi atlet sepak bola. Eksperimen selama 7 minggu dengan 13 sesi dilakukan dalam penelitian ini dengan desain penelitian pre and post training session. Atlet sepak bola Akademi Persib sebanyak 26 atlet putra dengan rata-rata usia latihan 5-6 tahun digunakan dalam penelitian ini. Instrumen penelitian yang digunakan adalah Concentration Grid Test (CGT) untuk mengukur konsentrasi atlet sebelum dan setelah diberikan treatment. Hasil penelitian menunjukkan bahwa metode latihan life kinetik yang diberikan memberikan pengaruh yang signifikan, sedangkan metode latihan konvensional yang diberikan tidak memberikan pengaruh yang signifikan terhadap peningkatan konsentrasi atlet sepak bola Akademi Persib. Penelitian ini memberikan kesimpulan bahwa metode latihan life kinetik dapat meningkatkan konsentrasi atlet sepak bola. Penulis menyarakan kepada praktisi sepak bola, baik itu pelatih maupun atlet untuk menggunakan metode latihan ini dalam proses pelatihan yang dijalani.
\end{abstract}

Kata Kunci: Life Kinetik; Konsentrasi; Atlet Sepak Bola

Increasing the Concentration of Football Athletes through the Life Kinetik Training Method

ABSTRACT

Concentration is one of the psychological aspects that is needed by athletes, but psychological training is still rarely done in football, so athletes often experience difficulties related to this. Therefore, it takes the right method of psychological training to help overcome these problems, one method of psychological training that is currently busy is the life kinetik training method. This study aims to examine the significant effect of the life kinetik training method on increasing the concentration of football athletes. Experiments for 7 weeks with 13 sessions were carried out in this study with a pre and post-training session research design. Persib Academy football athletes as many as 26 male athletes with an average training age of 56 years were used in this study. The research instrument used was the Concentration Grid Test $(C G T)$ to measure the athlete's concentration before and after being given treatment. The results showed that the given life kinetik training method had a significant effect, while the conventional training method provided did not have a significant effect on increasing the concentration of the Persib Academy football athletes. This study concludes that the life kinetik training method can increase the concentration of football athletes. The author suggests football practitioners, both coaches, and athletes, use this training method in the training process. 


\section{PENDAHULUAN}

Dalam permainan sepak bola, seseorang yang memainkannya membutuhkan berbagai komponen kondisi fisik yang baik dan teknik dasar yang mumpuni. Kolaborasi antara fisik dan teknik akan mampu meningkatkan mutu permainan sepak bola itu sendiri. Latihan teknik sendiri merupakan latihan khusus dimaksudkan guna membentuk dan memperkembang kebiasaan-kebiasaan motorik atau perkembangan neuromuscular, kesempurnaan teknik-teknik dasar dari setiap gerakan adalah penting oleh karena akan menentukan gerak keseluruhan (Harsono, 2017). Oleh karena itu, gerak dasar setiap teknik yang diperlukan dalam setiap cabang olahraga harus dilatih dan dikuasai secara sempurna. Karena tanpa adanya keterampilan gerak dasar yang baik, maka atlet akan kesulitan untuk memiliki keterampilan gerak lanjutan, terutama pada cabang olahraga sepak bola yang dinamis.

Selain itu juga, bermain sepak bola harus memiliki koordinasi gerak yang sangat baik, karena tanpa adanya koordinasi gerak yang baik, maka teknik dan fisik yang dijelaskan di atas akan sulit terealisasi. Koordinasi gerak sendiri merupakan kemampuan tubuh untuk mengintegrasikan berbagai gerakan yang berbeda menjadi tunggal menjadi harmonis dan efektif (Nala, 2011). Komponen koordinasi gerak ini juga merupakan gabungan berbagai komponen biomotorik lainnya, seperti kekuatan, kelentukan, kecepatan dan kelincahan yang seharusnya dikembangkan berdasarkan kematangan usia seseorang (Popović et al., 2020). Hal ini menunjukkan bahwa penting bagi atlet sepak bola untuk memiliki kapabilitas teknik, fisik dan koordinasi gerak yang baik agar dapat menampilkan performa maksimal.

Namun, dalam konteks pertandingan, ketiga hal yang disebutkan di atas tidak akan berfungsi maksimal jika tidak memiliki kondisi psikologis yang baik. Bahkan, studi menunjukkan bahwa psikologis memiliki peranan sebesar $70 \%$ dalam pertandingan (Hidayat, 2015). Hal ini mengindikasikan bahwa dengan kondisi psikologis yang baik, atlet memiliki kestabilan mental sehingga teknik, fisik dan koordinasi gerak yang sudah dilatih dapat ditampilkan dengan baik. Dengan demikian, untuk mencapai prestasi yang maksimal, atlet dan pelatih khususnya dalam cabang olahraga sepak bola tidak boleh hanya fokus pada teknik, fisik dan koordinasi gerak saja, namun harus memperhatikan psikologis atlet itu sendiri, karena kita ketahui bersama bahwa psikologis memiliki peranan penting dalam meningkatkan performa olahraga (Komarudin, 2016).

Dalam proses latihan pada suatu cabang olahraga, kemampuan fisik, teknik, dan taktik seseorang tidak akan meningkat secara signifikan, apabila tidak didukung kemampuan psikologis. Tidak bisa dipungkiri bahwa kemampuan psikologis merupakan salah satu faktor penentu yang mempengaruhi dalam pencapaian hasil prestasi. Oleh sebab itu, diperlukan latihan khusus guna meningkatkan kondisi psikologis atlet dengan berbagai metode latihan psikologis yang disusun dalam sebuah program latihan psikologis (Komarudin, 2018). Latihan psikologis sendiri berguna untuk mempertinggi 
efesiensi psikologis atlet, terutama apabila atlet berada dalam suatu situasi stres yang kompleks (Harsono, 2017). Jika atlet tidak pernah melakukan latihan psikologis, maka besar kemungkinan atlet akan kesulit menghadapi berbagai masalah yang akan dihadapi ketika seang berlatih maupun bertanding.

Program latihan psikologis sangat penting bagi atlet supaya atlet bisa fokus pada tugas-tugas yang harus dilakukan dan lebih fokus dalam mengarahkan potensi atau kemampuannya semaksimal mungkin. Dalam cabang olahraga sepak bola, kita ketahui bahwa terdapat berbagai tantangan menerpa dalam diri atlet saat pertandingan atau kompetisi yang tidak jarang menjatuhkan psikologis atlet itu sendiri. Fenomena seperti ini seharusnya sudah mampu diatasi mengingat perkembangan dunia olahraga yang kian hari kian pesat berkembang. Akan tetapi, sampai saat ini sebagian orang masih meragukan efektivitas program latihan psikologis bagi performa atlet sepak bola. Padahal studi literatur telah menunjukkan bahwa program latihan psikologis sangat diperlukan bagi atlet guna meningkatkan performa dan memperoleh prestasi maksimal (Komarudin, 2016, 2018). Terutama pada cabang olahraga sepak bola, salah satu faktor psikologis yang penting dikuasai atlet yaitu konsentrasi. Konsentrasi merupakan salah satu aspek psikologis yang sangat dibutuhkan oleh atlet sepak bola karena mengharuskan atlet untuk memusatkan pikiran terhadap suatu hal dengan mengesampingkan semua hal lainnya yang tidak berhubungan (Robbani \& Dimyati, 2019). Jika atlet sepak bola tidak memiliki konsentrasi yang baik, maka ia akan sulit memberikan performa terbaiknya dan cenderung akan merugikan tim.

Salah satu bentuk latihan psikologis yang saat ini sedang ramai digemari yaitu metode latihan life kinetik (Demirakca et al., 2016). Life kinetik merupakan metode latihan psikologis modern yang sangat berkembang dan populer di Western Europe, seperti di (Germany, the Netherlands, France, Spain). Latihan ini di Negara Eropa dilakukan rutin baik ditingkat lokal maupun internasional, sedangkan di Indonesia latihan life kinetik sendiri merupakan metode latihan yang tergolong baru dan belum banyak dilakukan (Komarudin, 2018). Padahal menurut studi literatur yang ada, life kinetik telah membuktikan memiliki efek positif yang signifikan bagi atlet yang melakukannya. Beberapa penelitian terdahulu telah mengujicobakan metode latihan ini terhadap berbagai aspek psikologis maupun fisiologis atlet (Cakir et al., 2020; Duda, 2015; Komarudin, 2019; Komarudin et al., 2020; Peker et al., 2018; Pietsch et al., 2017). Latihan ini sangat efektif untuk mempersiapkan para atlet menghadapi permainan yang tidak hanya menekankan pada kemampuan teknik, tetapi performa aktivitas gerak dalam kondisi perubahan gerak yang konstan untuk mencapai tujuan dalam permainan tersebut (Komarudin, 2018; Lutz, 2017).

Metode latihan life kinetik mempunyai peranan yang sangat penting dalam suatu proses latihan. Metode latihan life kinetik dapat menunjukkan cepat tidaknya atau mudah tidaknya seseorang menguasai suatu gerakan. Dengan demikian, atlet harus tangguh dalam aspek psikologis, karena jika tidak, atlet tidak dapat menguasai gerakan-gerakan yang dilatih, oleh karena itu harus dilatih melalui metode latihan life kinetik. Studi literatur 
telah mengemukakan berbagai manfaat dari penerapan latihan life kinetik terhadap berbagai aspek psikologis, namun masih belum ada studi yang spesifik mengkaji terkait konsentrasi pada atlet sepak bola. Penulis merasa studi ini perlu dilakukan dengan tujuan untuk mengkaji pengaruh metode latihan life kinetik terhadap peningkatan konsentrasi atlet sepak bola.

\section{METODE}

Metode penelitian yang penulis gunakan adalah metode eksperimen dengan desain penelitian pre and post training session. Sampel pada penelitian ini adalah atlet sepak bola Akademi Persib berjumlah 26 atlet putra yang berusia 16 tahun dengan rata-rata usia latihan 5-6 tahun. Sampel penelitian ini diambil dari populasi penelitian dengan menggunakan total sampling, yang berarti mengambil seluruh populasi menjadi sampel. Sampel diberikan dibagi secara acak kedalam dua kelompok, yaitu kelompok eksperimen dan kelompok kontrol. Kelompok eksperimen akan menerima treatment berupa latihan life kinetik dan kelompok kontrol melakukan latihan konvensional. Treatment dilakukan selama 7 minggu terdiri dari 13 sesi dengan frekuensi 2 sesi/minggu (Komarudin, 2019). Durasi dalam setiap pelaksanaannya adalah 20-30 menit dan dilakukan pada sesi warming up, sebelum masuk latihan inti. Perlakuan dilakukan pada setiap hari Senin pukul 14.00 dan Jumat pukul 16.00 di lapangan Akademi Persib.

Pelaksanaan latihan life kinetik yang dilakukan pada intensitas $60 \%$ dan dilakukan dalam suasana yang menyenangkan sehingga dapat meningkatkan produksi sel-sel baru di otak. Studi juga berpendapat bahwa atlet cukup menguasai $60 \%$ pada setiap bentuk latihan yang diberikan. Setelah atlet menguasai $60 \%$ gerakan yang diberikan, atlet boleh diberikan kesempatan untuk melakukan gerakan yang baru dan dapat menambahkan tingkat kesulitannya (Komarudin, 2018).

Instrumen yang digunakan dalam penelitian ini adalah Concentration Grid Test (CGT). CGT adalah sebuah tes yang digunakan untuk mengukur konsentrasi seseorang (Greenlees et al., 2006). Greenlees dalam studinya mengemukakan bahwa CGT terdiri dari 100 kotak yang disusun 10x10 dengan dua angka (dari 00-99) yang kemudian disusun secara acak. Atlet harus mengurutkan angka-angka tersebut dari yang terkecil hingga yang terbesar sebanyak-banyaknya dalam durasi 1 menit. CGT diberikan kepada atlet sebanyak dua kali, yaitu pada saat sebelum dan setelah menerima treatment. Setelah itu, data diolah dan dianalisis menggunakan SPSS versi 24 dengan menggunakan uji t (Santoso, 2017).

\section{HASIL}

Setelah data diperoleh, maka penulis mengolah dan menganalisis data, kemudian disajikan dalam bentuk tabel dan diagram untuk mempermudah dipahami, dapat dilihat pada Tabel 1. 
Tabel 1. Deskripsi Statistik

\begin{tabular}{|c|c|c|}
\hline \multicolumn{2}{|c|}{ Kelompok } & Rata-rata \pm Standar Deviasi \\
\hline \multirow{2}{*}{ Eksperimen } & Pre & $7,23 \pm 2,166$ \\
\hline & Post & $12,15 \pm 3,508$ \\
\hline \multirow{2}{*}{ Kontrol } & Pre & $9,38 \pm 3,150$ \\
\hline & Post & $8,54 \pm 3,045$ \\
\hline
\end{tabular}

Tabel 1 menunjukkan deskripsi statistik data penelitian. Diketahui bahwa nilai ratarata pre-test kelompok eksperimen sebesar 7,23 dengan standar devisasi sebesar 2,166 dan nilai rata-rata post-test kelompok ekperimen sebesar 12,15 dengan standar deviasi sebesar 3,508, sedangkan nilai rata-rata pre-test kelompok kontrol sebesar 9,38 dengan standar deviasi sebesar 3,150 dan nilai rata-rata post-test kelompok kontrol sebesar 8,54 dengan standar deviasi sebesar 3,045. Hal ini menunjukkan bahwa kelompok eksperimen mengalami peningkatan rata-rata kemampuan konsentrasi, sedangkan kelompok kontrol mengalami penurunan rata-rata kemampuan. Selanjutnya, penulis melakukan uji normalitas untuk mengetahui pendekatan yang akan digunakan dalam uji hipotesis, dapat dilihat pada Tabel 2.

Tabel 2. Uji Normalitas

\begin{tabular}{|c|c|c|}
\hline \multicolumn{2}{|c|}{ Kelompok } & Asymp. Sig. (2-tailed) \\
\hline \multirow{2}{*}{ Eksperimen } & Pre & 0,200 \\
\hline & Post & 0,200 \\
\hline \multirow{2}{*}{ Kontrol } & Pre & 0,200 \\
\hline & Post & 0,200 \\
\hline
\end{tabular}

Tabel 2 menunjukkan hasil uji normalitas menggunakan Kolmogorov-Smirnov Test. Berdasarkan hasil uji, diketahui bahwa nilai Asymp. Sig. (2-tailed) untuk kelompok eksperimen pada saat pre- dan post-test sebesar 0,200>0,05, maka dapat dinyatakan data kelompok eksperimen berdistribusi normal. Sedangkan kelompok kontrol, data pre- dan post-test memperoleh nilai Asymp. Sig. (2-tailed) sebesar 0,2000>0,05, maka dapat dinyatakan bahwa data kelompok kontrol berdistribusi normal. Karena seluruh data berdistribusi normal, maka penulis menggunakan pendekatan parametrik dalam penelitian ini.

Tabel 3. Uji Hipotesis

\begin{tabular}{cc}
\hline Kelompok & Sig. (2-tailed) \\
\hline Eksperimen & 0,001 \\
Kontrol & 0,068 \\
\hline
\end{tabular}


Tabel 3 menunjukkan hasil uji hipotesis menggunakan Paired Sample T-Test. Berdasarkan hasil uji, diperoleh nilai Sig. (2-tailed) kelompok eksperimen sebesar 0,001 dan kelompok kontrol sebesar 0,68. Diketahui bahwa nilai Sig. (2-tailed) kelompok eksperimen sebesar 0,001 <0,05, maka $\mathrm{H}_{0}$ ditolak dan $\mathrm{H}_{1}$ diterima, sedangkan nilai Sig. (2-tailed) kelompok kontrol sebesar 0,68 > 0,05 $\mathrm{H}_{0}$ diterima dan $\mathrm{H}_{1}$ ditolak. Hasil uji memberikan keputusan bahwa latihan life kinetik memberikan pengaruh yang signifikan terhadap peningkatan konsentrasi atlet sepak bola, sedangkan metode latihan konvensional tidak memberikan pengaruh yang signifikan terhadap peningkatkan konsentrasi atlet sepak bola.

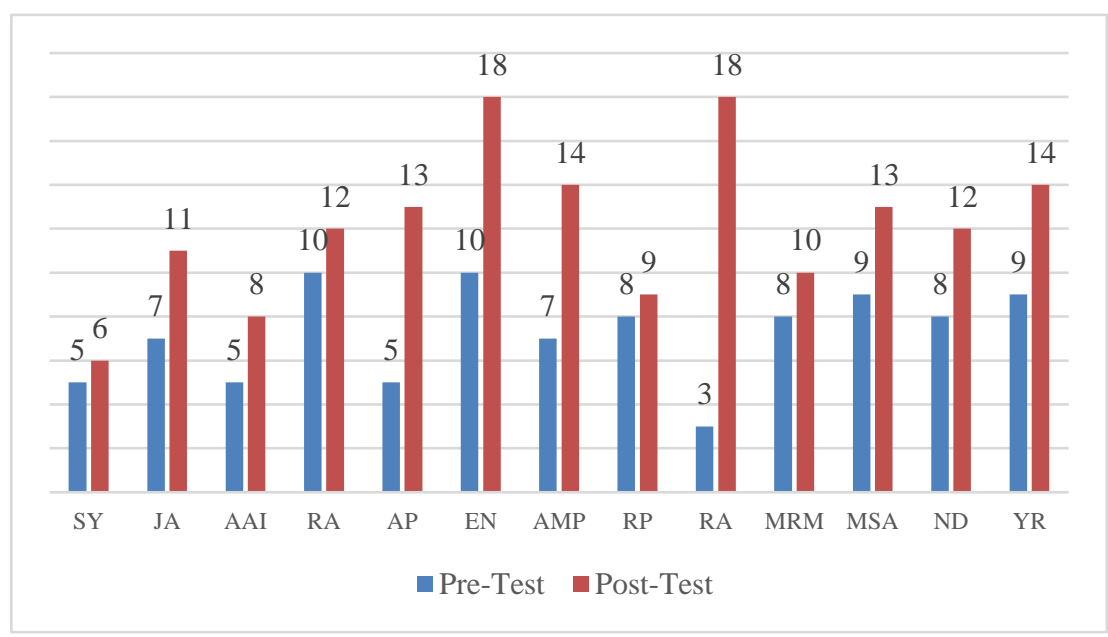

Gambar 1. Persentase Hasil Kelompok Eksperimen

Gambar 1 menunjukkan persentase hasil kelompok eksperimen pada pre- dan post-test. Dapat dilihat bahwa setiap sampel (13 atlet) mengalami peningkatan persentase hasil yang signifikan dari pre-dan post-test dengan gain sebesar 4,92 dan persentase peningkatan sebesar 25\%. Persentase peningkatan ini menunjukkan bahwa latihan life kinetik yang diberikan dapat meningkatkan kemampuan konsentrasi atlet sepak bola.

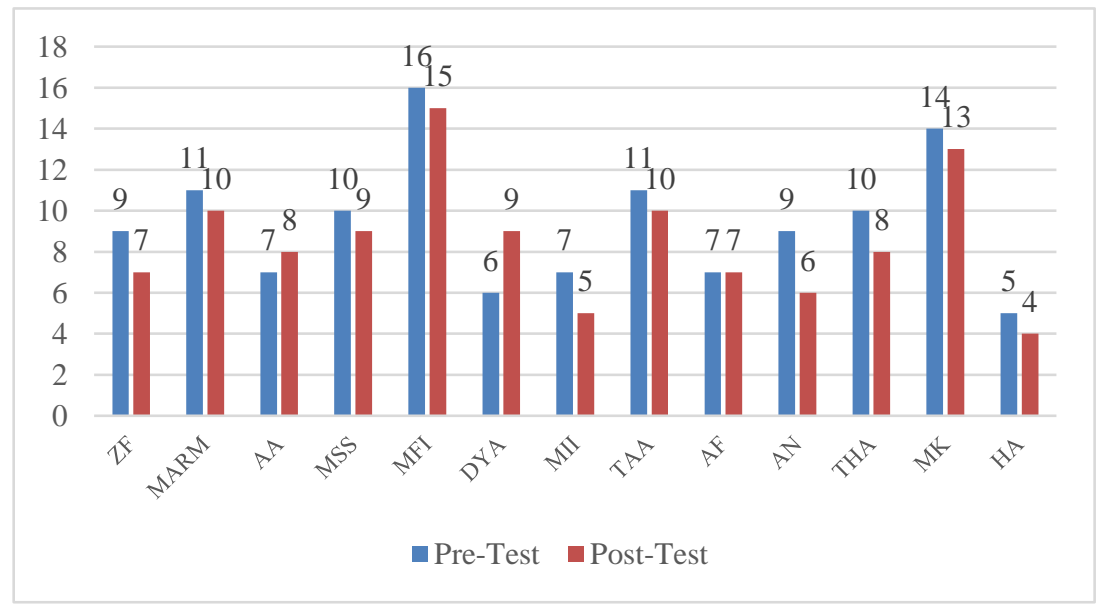

Gambar 2. Persentase Hasil Kelompok Kontrol 
Gambar 2 menunjukkan persentase hasil kelompok kontrol pada pre- dan posttest. Dapat dilihat bahwa tidak ada satupun sampel yang mengalami peningkatan hasil, 12 sampel mengalami penurunan yang signifikan dan 1 sampel tidak mengalami perubahan hasil. Penurunan yang terjadi pada kelompok kontrol memiliki gain sebesar 0,84 dengan persentase penurunan sebesar 5\%. Hal ini menunjukkan bahwa latihan konvensional yang diberikan kepada sampel tidak mampu meningkatkan kemampuan konsentrasi atlet sepak bola.

\section{PEMBAHASAN}

Studi terdahulu menjelaskan bahwa, life kinetik adalah program pelatihan aksi teknis modern yang didasarkan pada pembentukan kebiasaan lokomotif yang dipasangkan dengan aktivitas sistem saraf yang tinggi - terutama kecerdasan atlet (Duda, 2015). Life kinetik merupakan kombinasi aktivitas motorik dan tantangan kognitif dan pelatihan visual (Demirakca et al., 2016). Life kinetik merupakan cara latihan yang berbasis gerak dan hiburan dalam rangka meningkatkan mental atlet (Peker et al., 2018). Berdasarkan beberapa pendapat di atas, dapat disimpulkan bahwa metode latihan life kinetik adalah salah satu bentuk terapi yang berupa pemberian instruksi kepada seseorang dalam bentuk gerakan-gerakan yang tersusun secara sistematis melalui kinerja otak dan anggota tubuh (Komarudin, 2018).

Pada penelitian ini, diperoleh hasil bahwa terdapat pengaruh yang signifikan metode latihan life kinetik terhadap peningkatan konsentrasi atlet sepak bola. Selain dari hasil pengujian statistik, hal ini dibuktikan juga dengan peningkatan yang signifikan terjadi dari pre- dan post-test konsentrasi pada sampel sebesar $25 \%$. Sedangkan latihan konvensional yang diterapkan dalam penelitian ini tidak memberikan pengaruh yang signifikan dan memberikan penurunan persentase konsentrasi atlet sepak bola sebesar 5\%. Selain itu juga, berdasarkan wawancara singkat terhadap sampel, sampel merasa bahwa metode latihan life kinetik lebih bisa merangsang tingkat fokus yang dimiliki atlet dalam berlatih. Dalam pelaksanaannya, penerapan metode latihan life kinetik mengkombinasikan tiga komponen latihan, yaitu latihan aktivitas gerak, tantangan kognisi, dan latihan persepsi visual, terutama persepsi visual periferal (Demirakca et al., 2016). Atlet sepak bola akan dilatih untuk melakukan tugas ganda dalam bentuk latihan, sehingga tuntutan otak akan semakin lebih besar, namun tetap berada pada ambang kesenangan dengan intensitas yang tidak terlalu tinggi. Berbagai aktivitas gerak yang secara aktif membentuk hubungan di otak manusia, terutama dibagian kortikal, sehingga meningkatkan efisiensi atlet sepanjang latihan (Duda, 2015).

Metode latihan life kinetik yang diterapkan pada atlet sepak bola dapat divariasikan sesuai dengan kebutuhan cabang olahraga dan kategori usia yang dilatih, namun tetap mengikuti panduan dasar penyusunan program latihan life kinetik (Komarudin, 2018). Latihan ini akan sangat menguntungkan bagi atlet sepak bola karena akan mampu meningkatkan konsentrasinya dengan penerapan latihan life kinetik yang dilakukan. Seperti contoh dengan menerapkan bentuk latihan ladder dan kombinasi 
dengan cones ataupun bola akan membuat atlet terpacu untuk mampu menyelesaikan berbagai tugas yang datang secara bersamaan. Namun, perlu diperhatikan bahwa metode latihan life kinetik harus dilakukan dalam kondisi yang tidak melelahkan agar manfaat yang diperoleh tetap tercapai, khususnya bagi dalam cabang olahraga sepak bola untuk meningkatkan konsentrasinya (Komarudin \& Awwaludin, 2019).

Latihan life kinetik juga mampu meningkatkan konsentrasi atlet karena merangsang sel-sel otak dan sangat cocok untuk anak-anak, orang dewasa dan atlet, baik atlet tim maupun individu (Lutz, 2017). Latihan ini merangsang struktur kinerja otak dengan berbagai tantangan maupun stimulus guna mengoptimalkan kemampuan daya selsel otak. Latihan ini juga berfungsi untuk menstimulasi otak dan meningkatkan fungsi kognisi atlet, karena atlet tidak hanya dituntut unggul dalam kemampuan fisik, teknik, taktik, namun atlet juga dituntut cerdas dan memiliki kemampuan untuk fokus dalam menampilkan tugasnya (Komarudin, 2018). Penelitian terdahulu juga mengemukakan bahwa latihan life kinetik dapat memperbaiki kinerja kognitif, koordinasi dan tingkat kebugaran atlet (Cakir et al., 2020; Cancela et al., 2015; Komarudin, 2019) (Cancela et al., 2015; Komarudin, 2018).

Penting bagi pelatih untuk lebih update perihal metode-metode latihan yang harus digunakan, serta pelatih juga harus mulai lebih sadar akan pentingnya latihan mental pada proses pelatihan. Konsep serta bentuk latihan yang konvensional harus mulai ditinggalkan dan diperbaharui oleh pelatih dengan menggunakan pendekatan ilmiah, karena memang hal inilah yang sangat membantu atlet untuk mencapai performa optimalnya. Metode latihan life kinetik membuat atlet tetap tertarik dan senang melakukan gerakan demi gerakan tanpa mengalami kelelahan. Latihan life kinetik sangat menghindari latihan yang monoton, membosankan, dan membuat atlet frustrasi dalam melakukan pola gerak. Hal yang harus diingat oleh para pelatih adalah latihan dengan pola gerak yang kompleks prosesnya melibatkan sistem koordinasi syaraf dan otot (neuromuscular-system), oleh sebab itu atlet tidak boleh melakukan gerakan sampai lelah, jika kondisi atlet lelah maka atlet tidak akan mampu melakukan gerakan koordinasi, kombinasi, dan akurasi gerak dengan baik.

\section{KESIMPULAN}

Berdasarkan hasil penelitian, maka penulis dapat menarik simpulan bahwa metode latihan life kinetik dapat meningkatkan konsentrasi atlet sepak bola. Selain itu, penulis juga memberikan beberapa saran, yaitu latihan psikologis harus dilakukan dalam proses pelatihan, metode latihan yang tepat akan sangat membantu atlet secara efisien untuk mencapai performa maksimal yang berujung pada sebuah prestasi. Penelitian ini masih sangat terbatas dari segi karakteristik sampel, penulis berharap adanya penelitian lebih lanjut terkait hal ini. 


\section{DAFTAR PUSTAKA}

Cakir, B. A., Turkkan, M., \& Ozer, O. (2020). Effects of adding cognitive motor coordination exercise to soccer training vs. soccer training alone on physical fitness of prepubescent boys. International Journal of Applied Exercise Physiology, 9(6), $250-259$.

Cancela, J. M., Vila Suárez, M. H., Vasconcelos, J., Lima, A., \& Ayán, C. (2015). Efficacy of brain gym training on the cognitive performance and fitness level of active older adults: A preliminary study. Journal of Aging and Physical Activity, 23(4), 653-658. https://doi.org/10.1123/japa.2014-0044

Demirakca, T., Cardinale, V., Dehn, S., Ruf, M., \& Ende, G. (2016). The exercising brain: Changes in functional connectivity induced by an integrated multimodal cognitive and whole-body coordination training. Neural Plasticity, 2016. https://doi.org/10.1155/2016/8240894

Duda, H. (2015). Application of life kinetik in the process of teaching technical activities to young football players. Journal of Kinesiology and Exercise Sciences, 71(25), 5363. https://doi.org/10.5604/17310652.1203803

Greenlees, I., Thelwell, R., \& Holder, T. (2006). Examining the efficacy of the concentration grid exercise as a concentration enhancement exercise. Psychology of Sport and Exercise, 7, 29-39. https://doi.org/10.1016/j.psychsport.2005.02.001

Harsono. (2017). Kepelatihan Olahraga: Teori dan Metodologi. Bandung: PT. Remaja Rosdakarya.

Hidayat, Y. (2015). Psikologi Olahraga. CV. Bintang WarliArtika.

Komarudin. (2016). Psikologi Olahraga. Bandung: PT. Remaja Rosdakarya.

Komarudin. (2018). Life Kinetik dan Performa Psikologis. PT. Remaja Rosdakarya.

Komarudin. (2019). Life kinetic training in improving the cognitive functions. 2nd International Conference on Sports Sciences and Health 2018 (ICSSH 2018), 7, 107-110. https://doi.org/10.2991/icssh-18.2019.25

Komarudin, K., \& Awwaludin, P. N. (2019). Life kinetik training in improving the physical condition of football athletes. 3rd International Conference on Sport Science, Health, and Physical Education (ICSSHPE 2018) Life, 11, 182-185. https://doi.org/10.2991/icsshpe-18.2019.52

Komarudin, K., Nurcahya, Y., Nurmansyah, P., \& Kusumah, W. (2020). The influence of life kinetic training method and motor educability on improvement of football playing performance. 4th International Conference on Sport Science, Health, and Physical Education (ICSSHPE 2019), 21, 276-279. https://doi.org/10.2991/ahsr.k.200214.073

Lutz. (2017). Perform Better with Life Kinetik Life.

Nala, I. G. N. (2011). Prinsip Pelatihan Fisik Olahraga. Udayana University Press.

Peker, T., Effect, T., Life, O., Trainings, K., \& Coordinative, O. (2018). The effect of life kinetic trainings on coordinative abilities. Journal of International Multidisciplinary 
Academic Researches, 5(3), 55-67.

Pietsch, S., Böttcher, C., \& Jansen, P. (2017). Cognitive motor coordination training improves mental rotation performance in primary school-aged children. Mind, Brain, and Education, 11(4), 176-180. https://doi.org/10.1111/mbe.12154

Popović, B., Gušić, M., Radanović, D., Andrašić, S., Madić, D. M., Mačak, D., Stupar, D., Đukić, G., Grujičić, D., \& Trajković, N. (2020). Evaluation of gross motor coordination and physical fitness in children: Comparison between soccer and multisport activities. International Journal of Environmental Research and Public Health, 17(16), 1-10. https://doi.org/10.3390/ijerph17165902

Robbani, F. I., \& Dimyati. (2019). Psychological skills of soccer players based on gender perspective. Journal of Physical Education, Sport, Health and Recreation, 8(1), 4450. http://journal.unnes.ac.id/sju/index.php/peshr

Santoso, S. (2017). Complete Guide to Mastering Statistics with SPSS 24. Jakarta: PT. Elex Media Komputindo. 